\title{
諏訪湖における多環芳香族炭化水素類污染の 特徵とその集水域との関係
}

\author{
池中 良徳，館野 覚俊，宮原 裕一 \\ 信州大学山岳科学総合研究所山地水域環境保全学部門（†392-0027 長野県諏訪市湖岸通り5-2-4）
}

[平成18年12月15日受理］

\section{The Characteristic of Polycyclic Aromatic Hydrocarbons Pollution in Eutrophic Lake "Lake Suwa" and Relations with its Catchment Area}

\author{
Yoshinori IKENAKA, Akitoshi TATENO and Yuichi MIYABARA \\ Division of Science for Inland Water Environment, \\ Institute of Mountain Science, Shinshu University \\ (5-2-4 Kogandori, Suwa, Nagano 392-0027)
}

[Received December 15, 2006]

\begin{abstract}
Summary
In the present study, we investigated the Polycyclic Aromatic Hydrocarbons (PAHs) at the representative eutrophic lake "Lake Suwa", which has drastically eutrophicated since 1960s by inflow of domestic and industrial effluents. We also investigated PAHs in river sediments, road dusts, suspended solids and air particles of the catchment area of Lake Suwa.

We showed that the concentrations of $\sum 17 \mathrm{PAHs}$ in the lake sediments and river sediments were $364 \pm 129 \mathrm{ng} / \mathrm{g}$-dry and $157 \pm 194 \mathrm{ng} / \mathrm{g}$-dry, respectively. On the other hand, the concentrations of $\Sigma 17 \mathrm{PAHs}$ in sediments were relatively high in the northeast part of Lake Suwa.

One of the major PAHs in the sediment of Lake Suwa was perylene. It would be mainly produced from precursor substances (such as perylenequinone) in anoxic lake sediment. On the other hand, the major sources of other PAHs (except perylene) were considered to be both petrogenic and pyrogenic source as diesel exhaust matter and asphalt. They entered the Lake Suwa through rivers and finally precipitated to lake sediment.
\end{abstract}

Key words: Lake Suwa, Polycyclic Aromatic Hydrocarbons, Perylene, Sources

\section{1. はじめに}

我が国の富栄養湖は, 集水域の人間活動に伴う栄養塩 負荷の影響を強く受けている。また，同時に富栄養湖 は，工業や農業といった人間活動により排出されるその 他の化学物質の影響も受けやすく, 重金属類や農薬がそ の生態系に何らかの影響をおよぼしている可能性があ
る。長野県で最も大きな湖である諏訪湖も1960年代に生 活廃水や工業廃水の流入による, 急激な富栄養化が進行 したが，それと同時にカドミウムやクロム等の重金属や PCBs, DDT, ダイオキシン類等の有機塩素系化合物が 湖内に流入し, それらの生物への影響が懸念された ${ }^{1-4)}$ 。 最近, 我々は諏訪湖湖心で堆積物柱状試料を採取し, ダ イオキシン類扔よび多環芳香族炭化水素類 (PAHs) 污 
染の歴史的変遷を調查し, それら污染物質の流入負荷量 は1970年代に最大となり, その後, その流入負荷量が減 少していることを明らかにしだ5。また，そこで検出さ れたダイオキシン類は, その異性体組成から, 過去に水 田用除草剂として使用されていたペンタクロロフェノー ルやクロロニトロフェンの不純物として含まれていたも のであり, 水田の広がる諏訪湖の南側から主に流入した ものと考えられた6)。一方, PAHs は, フェナントレンと アントラセンの比から燃焼由来である可能性が示唆され たが，その詳細な発生源や流入経路を明らかにすること はできなかった。

一方, 我々は, 堆積物中の PAHs を Till et al. ${ }^{7}$ の TCDD 毒性等量換算係数 (TEF) を用い, TCDD の毒性 等量（TEQ）に換算したところ，その PAHsの TEQはダ イオキシン類の TEQ に匹敵することを明らかにした5)。 PAHsには, 急性毒性, 変異原性, 発ガン性を有するも のが多く含まれているほか, 発ガン促進性を示すものも あることが知られている ${ }^{8.9}$ 。湖沼生態系におよぼす PAHs の影響を把握するためには, PAHsのより詳細な発 生源や流入経路に関する知見が必要と言える。

そこで本研究では, 諏訪湖に扔ける PAHs の詳細な発 生源や流入経路を解明することを目的とし, 諏訪湖およ
び，その集水域に扔いて，底質または土䁃を採取し，そ のPAHs 含量と組成を調査した。

\section{2. 実験方法}

\section{1 諏訪湖および諏訪湖集水域}

諏訪湖は, 東経 138 度 05 分, 北緯 36 度 03 分, 標高 $759 \mathrm{~m}$, 長野県で最も標高の高い盆地である諏訪盆地の北側に位 置し, 今から約100万年前に, 静岡 - 糸魚川構造線の西 崖に生じた地殼の変動によってできた断層湖である。平 均水深約 $4 \mathrm{~m}$, 最大水深でも $6.3 \mathrm{~m}$ と浅い湖で, 湖面積は

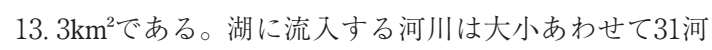
川あり, 代表的な河川として, 北側から流入する横河川 と砥川, 南東から流入する上川と宮川がある。また, 流

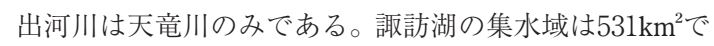
あり, 湖面積の40倍と集水域面積が広いのが特徵であ る。諏訪湖集水域では, 過去には製糸産業, 現在では精 密機械産業が盛んである。

\section{2 諏訪湖および流入河川底質の試料採取方法}

諏訪湖底質の試料採取は, 湖内計16地点 $(\mathrm{L} 1 \sim \mathrm{L} 16)$ で行った（Fig. 1)。流入河川底質の試料採取は, 上川,

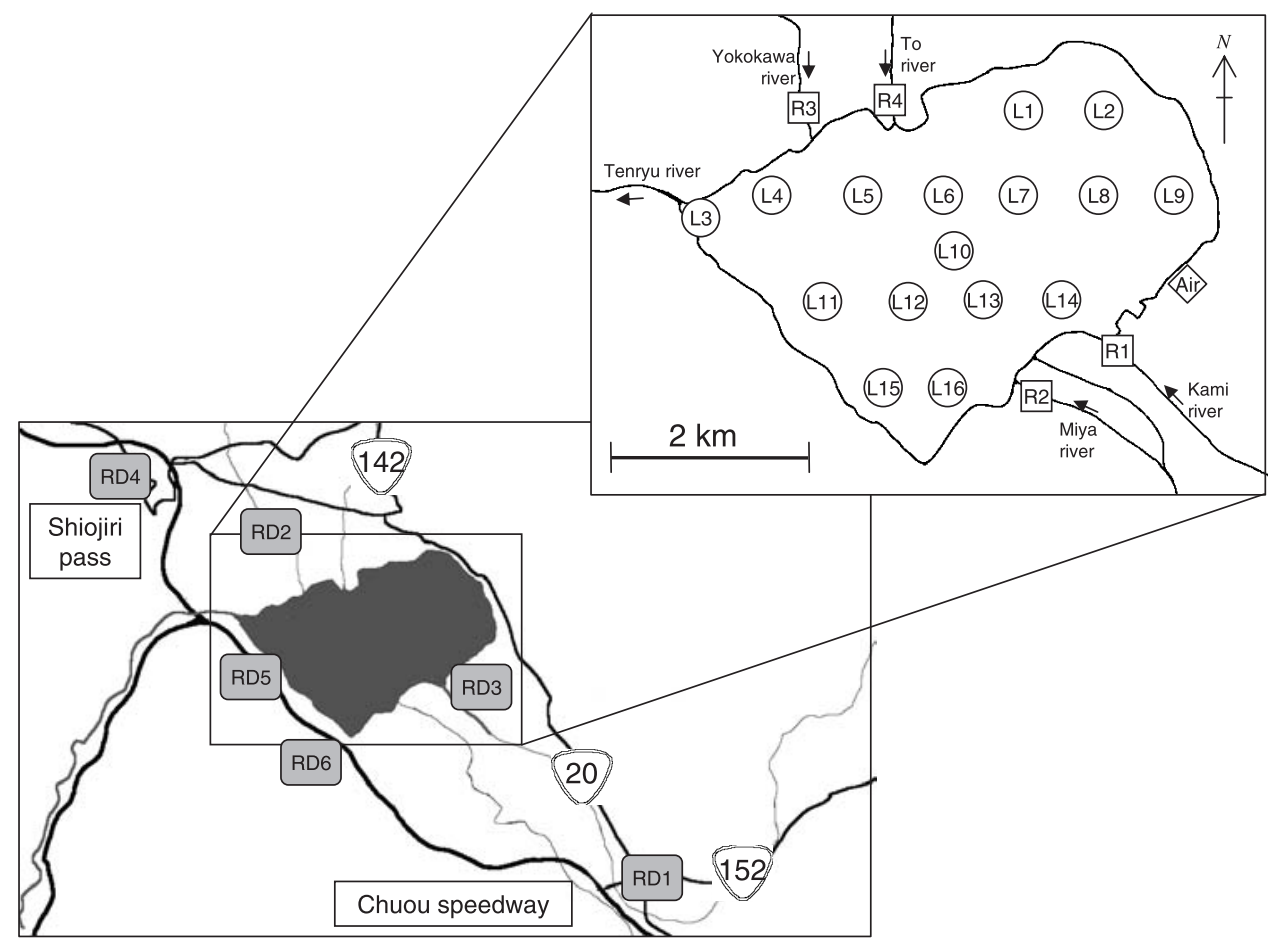

Fig. 1 Sampling sites of lake sediments, river sediments, road dusts and air particles $\mathrm{L} 1 \sim \mathrm{L} 16, \mathrm{R} 1 \sim \mathrm{R} 4, \mathrm{RD} 1 \sim \mathrm{RD} 6$ and Air shows the sampling sites of lake sediments, river sediments, road dusts and air particles, respectively 
宮川，横河川，砥川の河口付近（R1〜R 4) で行った (Fig. 1)。諏訪湖および流入河川底質の試料採取は 2002 年 5 月に行ない, エクマンバージ採泥器を用い, 底質表 層約 $0 \sim 5 \mathrm{~cm}$ を採取し, 分析まで $-20^{\circ} \mathrm{C}$ で保存した。

\section{3 諏訪湖および流入河川䯚濁粒子の試料採取方法}

2004年 4 月から 2005年 4 月まで定期的に, 諏訪湖湖心 （L10），流入河川河口付近（R1 R 4) で水試料を，それ ぞれ計19回採取した。採取した水試料は実験室に持ち帰 り, 直ちにガラス纎維滤紙 $(\mathrm{GF} / \mathrm{C})$ でろ過し, 懸濁物質 （SS）を集めた。

\section{4 諏訪湖集水域の道路脇土壤の試料採取方法}

諏訪湖集水域の道路脇土壤の採取は，茅野市街地，岡 谷市街地, 諏訪市街地, 塩尻峠, 諏訪湖の西側を走る中 央自動車道, および諏訪湖サービスエリア $(\mathrm{RD} 1 \sim \mathrm{R} \mathrm{D}$

6）で2002年10月に行なった（Fig. 1)。

\section{5 諏訪湖周辺の大気浮遊粉じんの試料採取方法}

大気浮遊粉じん試料はローボリウムエアーサンプラー （Sibata，SL-30PB）を用い，2002年 7 月から10月に諏訪 湖湖岸沿いで計 3 回捕集した（Fig. 1)。ローボリウムエ アーサンプラーの吸引速度は約 $20 \ell /$ 分とし，それぞれ約 100時間，ガラス瀻維濾紙上に大気浮遊粉じんを捕集し た。

\section{6 各試料の含水率, みかけ密度, 灼熱減量}

試料の性状として, 含水率, 久かけ密度, 灼熱減量を 測定した。灼熱減量は, 電気炉中で底質や土壤を $600^{\circ} \mathrm{C}$ で加熱し, その減量から求めた。湿泥の見かけ密度は, 土壤や底質の含水率から，以下の（1）式で求めた。灼 熱減量, みかけ密度はそれぞれ土壤や底質の有機物含 量，粒径の指標として用いた ${ }^{10,11}$ 。

$$
D a=\frac{W d r y}{\frac{W d r y}{2.65}+\frac{W w e t-W d r y}{1.00}}
$$

$D a$ : 久かけ密度 $\left(\mathrm{g} / \mathrm{cm}^{3}\right), W d r y$ : 乾燥重量 $(\mathrm{g})$, Wwet: 湿重量 $(\mathrm{g}), 2.65$ : 石英の密度 $\left(\mathrm{g} / \mathrm{cm}^{3}\right), 1.00$ : 水の密 度 $\left(\mathrm{g} / \mathrm{cm}^{3}\right)$

\section{7 分析対象のPAHs および定量に用いた内部標準物 質}

本研究ではEPAに指定されている16種の PAHs, naphthalene (Nap), acenaphthylene (Ace), acenaphthene (Acn), fluorene (Fle), phenanthrene (Phe), anthracene (Ant), fluoranthene (Flu), pyrene (Pyr), benz $[a]$ anthracene $(\mathrm{BaA})$, chrysene $(\mathrm{Chr})$, benzo[k]fluoranthene $(\mathrm{BkF})$, benzo [b]fluoranthene $(\mathrm{BbF})$, benzo[a]pyrene $(\mathrm{BaP})$, indeno [1,2,3-cd]pyrene (IDP), dibenz $[a, h]$ anthracene (DBahA), benzo[ghi]perylene (BghiP) に benzo[e]pyrene (BeP), perylene(Per) を加えた計18種のPAHs を分析対象とし た。本研究では, これら18種の PAHs の総量を総PAHs と表記し，Perを除いた17種の PAHs の総量を $\sum 17 \mathrm{PAHs}$ と表記する。分析した試料は内部標準法で定量し, 内部 標準物質（IS）として acenaphthene-d10, phenanthrened10, chrysene-d12, perylene-d12を用いた。各ISのグ ループ分けとして, acenaphthene-d10はN ap, Ace, Acn, Fle を定量対象に, phenanthrene-d10はPhe, Ant, Flu, Pyr を定量対象に, chrysene-d12は BaA, Chr を対象に, perylene-d12は残り 8 種類の PAHs を定量対象とした。

PAHs おうよ゙ IS のSTD は関東化学株式会社より購入し た。

\section{8 PAHs の抽出方法}

約 $20 \mathrm{~g}$ の底質掞よび土壤を精秤し，IS を添加し数時間 放置した後, アセトンで 3 回, 超音波抽出を行なった。 大気浮遊粉じんはIS を添加し，ガラス瀻維濾紙ごとア セトンで18時間以上ソックスレー抽出を行なった。一 方, SS 中 PAHs 量は, 蛍光検出器付高速液体クロマトグ ラフ ( $\mathrm{LC} / \mathrm{FD})$ を用い, 絶対検量線法で定量を行うた め, SSには IS を添加しなかった。SS も大気浮遊粉じん 同様，ガラス纎維滤紙ごとアセトンで18時間以上ソック スレー抽出を行なった。

\section{2. $9 \mathrm{PAHs}$ の精製方法}

各試料は抽出後, ロータリーエバポレーターでアセ卜 ン溶液を約 $1 \mathrm{~m} \ell$ まで濃縮し， $5 \% \mathrm{NaCl}$ 水溶液とへキサ ンで液一液抽出し, 水溶性成分を除去した。PAHs を含む ヘキサン相は無水硫酸ナトリウムで脱水し，濃縮後，硫 黄を除去するために銅線を入れて数時間放置した。硫黄 を除去したへキサン相を $5 \%$ 含水シリカゲル（カラム直 径：10mm， 5 \%含水シリカゲル：2. $5 \mathrm{~g}$ ）を用いたカラム クロマトグラフィーで精製し，PAHs 画分をアセトン/へ

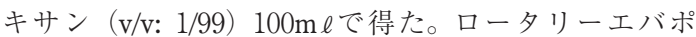

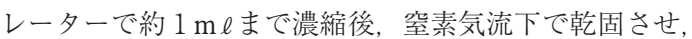
ガスクロマトグラフ/質量分析法 (GC/MS) では, $200 \mu \ell$

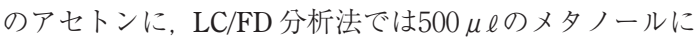
転溶した。

\section{10 機器分析}

諏訪湖求よび流入河川の底質，大気浮遊粉じん試料中 の PAHs はキャピラリーカラム (Agilent, DB-5/MS) を 装着した GC/MS（GC: 島津, GC-17A, MS: 島津, QP5050A）で分析を行なった。

一方，諏訪湖㧍よび流入河川 SS 中の PAHs は ODS カ ラム（関東化学, Mightysil RP-18 GP) を装着した 
LC/FD（HPLC: 島津, LC-VP series, FD: 島津, RF10AXL)，で分析を行なった。

GC/MS および LC/FD の分析条件は, Table 1 にまとめ て示した。

\section{11 統計処理}

Shapiro-Wilk 検定を用い, 標本の正規性を検定した結 果, 正規分布に従っていたので $(p<0.05)$, 本研究では パラメトリック検定を用い有意差検定を行なった。2 群 間の有意差検定は Student の $\mathrm{t}$ 検定で, 3 群間以上の有 意差検定は Tukey-Kramer 検定で行なった。クラスター 分析は, ユークリッド距離ーウォード法で行なった。 Student $の \mathrm{t}$ 検定, Tukey-Kramer 検定は JMP IN 5. 1. 2 を用い, クラスター分析は Excel 多変量解析4.0を用い た。

\section{3. 結果}

\section{1 試料の性状}

本研究で採取した試料の含水率, 从かけ密度, 灼熱減 量を Table 2 にまとめて示した。諏訪湖底質は, 流入河 川底質や道路脇土壤に比べみかけ密度が有意に低く, 灼 熱減量が有意に高かった（ $\mathrm{t}$ 検定 $p<0.05 ）$ 。すなわち, 諏訪湖底質は流入河川底質に比べ底質の圧密度が小さ く，有機物が多く含まれていることが明らかになった。 一方, 諏訪湖の SS は河川のSSに対し, 有意に灼熱減量

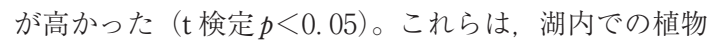
プランクトンの増殖によるものと言える ${ }^{12)}$ 。

\section{2 諏訪湖および流入河川底質中の PAHs 濃度}

諏訪湖拧よび流入河川底質中の PAHs 濃度を Fig. 2 に 示した。諏訪湖底質では, Per濃度が最も高く $566 \pm 317 n g / g-d r y$ (平均 \pm SD) であり, 次いで Flu

Table 1 GC/MS and LC/FD conditions

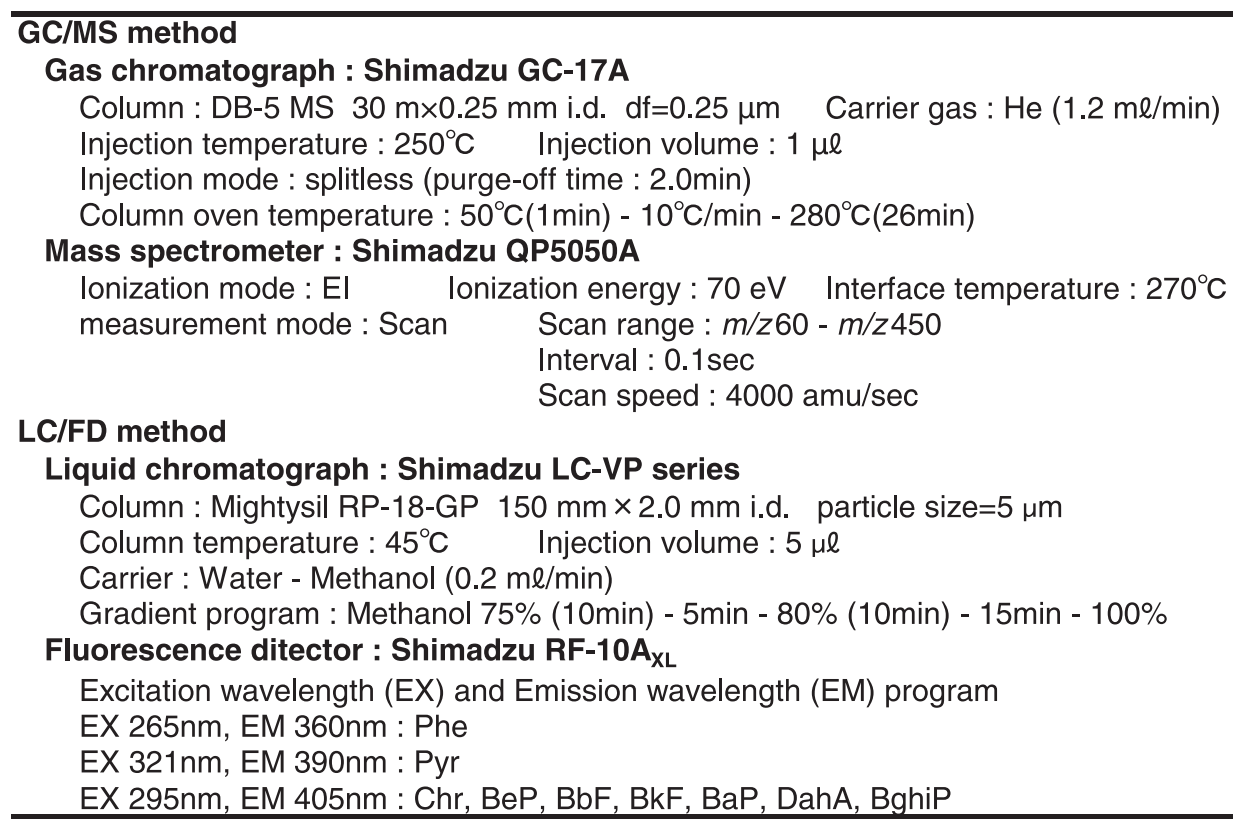

Table 2 Water content, apparent density and ignition loss of each sample

\begin{tabular}{lccc}
\hline & Water content (\%) & Apparent density $\left(\mathrm{g} / \mathrm{cm}^{3}\right)$ & Ignition loss $(\%)$ \\
\hline Lake sediments & $65.5 \pm 16.5$ & $0.5 \pm 0.3$ & $14.6 \pm 4.6$ \\
River sediments & $33.6 \pm 13.1$ & $1.2 \pm 0.4$ & $6.0 \pm 5.6$ \\
Road dusts & $8.5 \pm 10.3$ & $2.2 \pm 0.5$ & $5.3 \pm 3.2$ \\
Lake SS & - & - & $54.3 \pm 11.1$ \\
River SS & - & - & $33.2 \pm 8.0$ \\
\hline
\end{tabular}




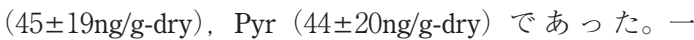
方, 流入河川底質では Pyr 濃度が最も高く $(25 \pm 38 n g / g-$ dry), 次 いで Flu $(22 \pm 32 n g / g-d r y)$, Phe $(19 \pm 28 n g / g-$ dry）であり，諏訪湖底質で濃度が最も高かったPerの濃 度は12 $\pm 16 n g / g-d r y$ と，その濃度，割合ともに低かった。

\section{3 諏訪湖および流入河川底質表層での PAHs の分布}

諏訪湖16地点および流入河川 4 地点の， $\sum 17 \mathrm{PAHs}$ 濃 度の分布をFig. 3 に示した。諏訪湖湖内では, 北東部

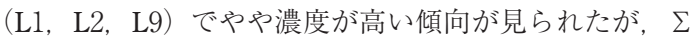
17PAHs 濃度に大きな差は見られなかった。一方，諏訪 湖底質中の $\sum 17 \mathrm{PAHs}$ 濃度は364 $\pm 129 \mathrm{ng} / \mathrm{g}$-dry であり, 流 入河川底質 $(157 \pm 194 \mathrm{ng} / \mathrm{g}$-dry）に比べ, 有意に高かっ た（ $\mathrm{t}$ 検定 $p<0.05 ） 。$ 諏訪湖および流入河川底質の灼熱 減量およびみかけ密度と, PAHs 濃度との相関を Fig. 4 に示した。灼熱減量と $\sum 17 \mathrm{PAHs}$ 濃度には正の相関が見 られ $\left(\mathrm{R}^{2}=0.502\right)$, 一方, みかけ密度と PAHs 濃度には 負の相関が見られた $\left(\mathrm{R}^{2}=0.497\right)$ 。概して有機物量が多
いほど，PAHs が高いことが確認された。

\section{4 諏訪湖底質中PAHs と道路脇土壤, 水中懸濁粒} 子, 大気浮遊粉じん中 PAHs の関係

諏訪湖および流入河川底質，道路脇土壤，水中懸濁粒 子, 大気浮遊粉じん中 $\sum 17 \mathrm{PAHs}$ 濃度を灼熱減量あたり に換算し, Fig. 5 に示した。PAHs 濃度を灼熱減量あたり に換算することにより, 性状の異なる底質を標準化し た。大気浮遊粉じん中 $\sum 17 \mathrm{PAHs}$ 濃度が最も高く $(64.2 \pm 28.7 \mu \mathrm{g} / \mathrm{g}-\mathrm{IL})$, 次いで道路脇土壤 $(10.3 \pm 2.6$ $\mu \mathrm{g} / \mathrm{g}$-IL) であった。一方, 諏訪湖および流入河川底質中 の $\sum 17 \mathrm{PAHs}$ 濃度は灼熱減量あたりに換算すると, それ ぞれ $2.3 \pm 0.6,2.2 \pm 0.7 \mu \mathrm{g} / \mathrm{g}-\mathrm{IL}$ であり，有意差は見られ なかった（t 検定 $p>0.05 ） 。 \mathrm{SS}$ 中の PAHs 濃度は, 湖内

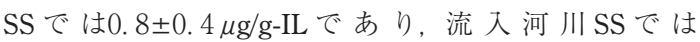
3. $6 \pm 3.4 \mu \mathrm{g} / \mathrm{g}-\mathrm{IL}$ であった。

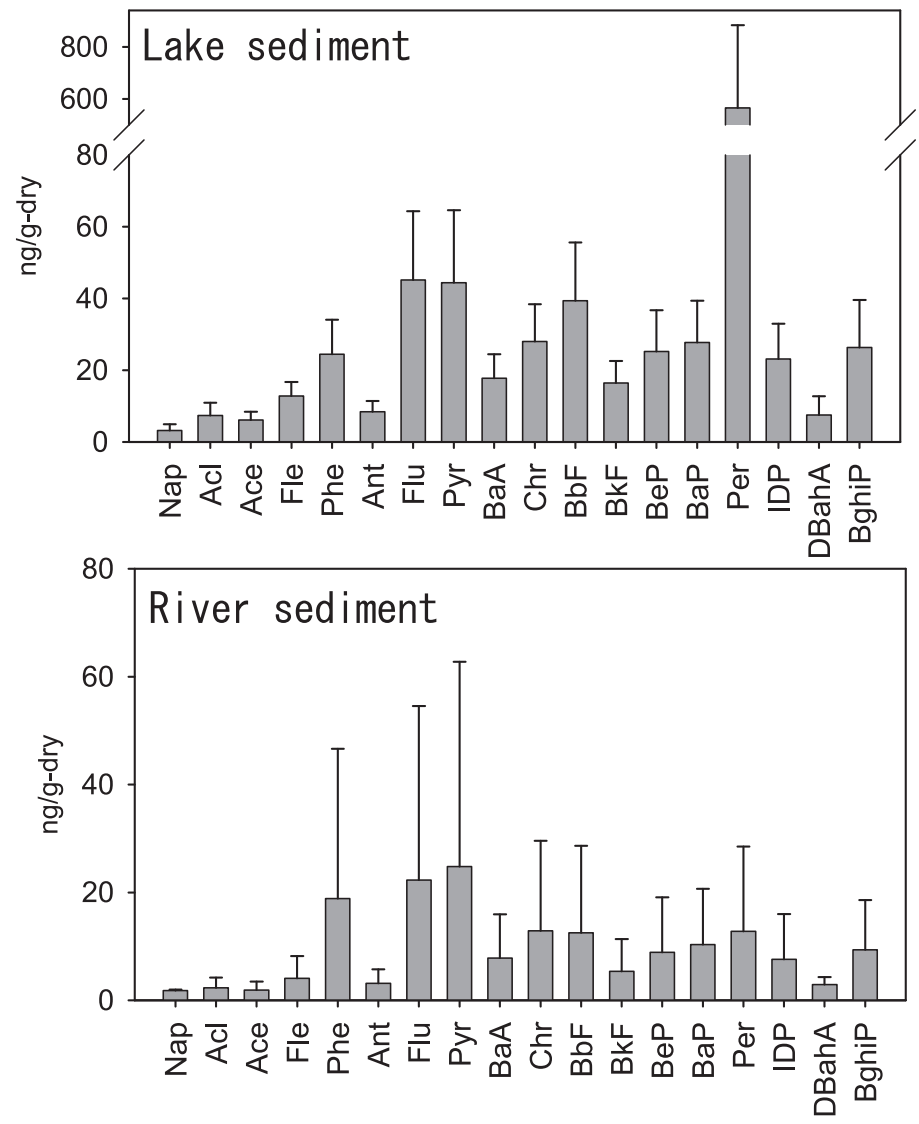

Fig. 2 Concentration of each $\mathrm{PAH}$ in lake and river sediment

Solid bar shows the average concentration of each PAH and $\mathrm{T}$ line shows the standard deviation (lake sediment $\mathrm{n}$ $=16$, River sediment $\mathrm{n}=4$ ) 


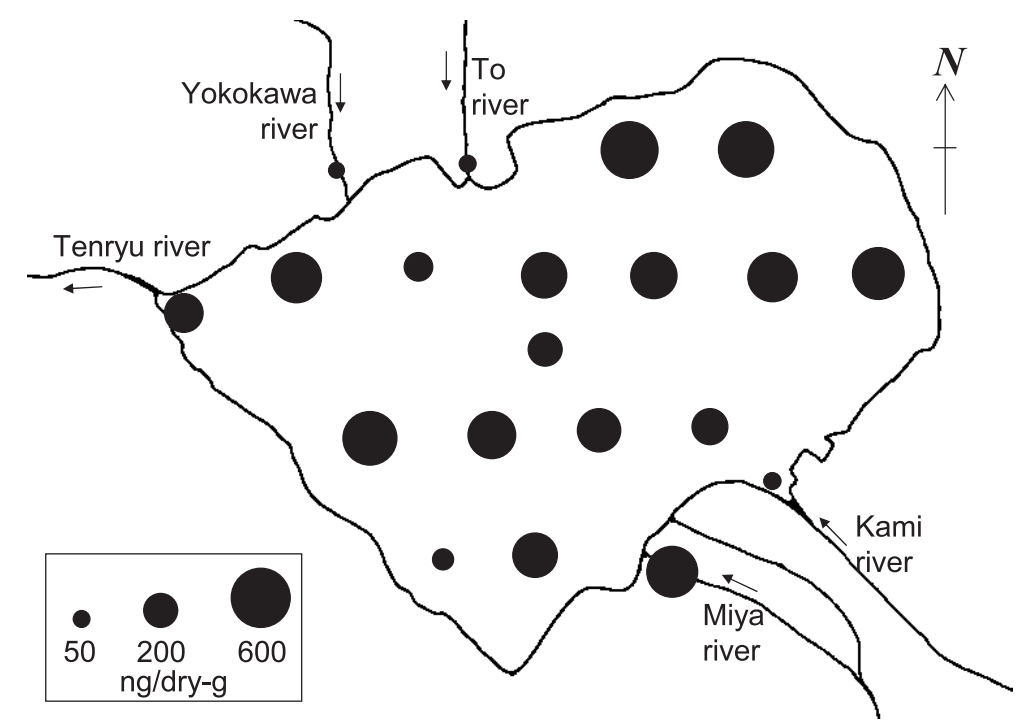

Fig. 3 Spatial distribution of $\sum 17 \mathrm{PAHs}$ in lake and river sediments

Area of each circle shows concentration of $\Sigma 17 \mathrm{PAHs}$. Concentration of $\Sigma 17 \mathrm{PAHs}$ was significantly higher in lake sediment compared to river sediment. On the other hands, in lake sediment, there is a tendency that concentration is high with L1, L2 and L9 position

\section{5 クラスター分析による諏訪湖底質中PAHs の発生 源解析}

諏訪湖底質中 PAHs の発生源を解析するため, クラス ター分析を行なった。本研究では, 発生源のデータとし

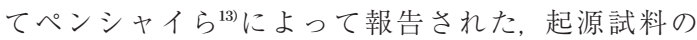
$\mathrm{PAHs}$ プロファイル（S1〜S 6) を基に分類を行なった。 S1〜S 6の具体的なプロファイルは Table 3 に示した。ク ラスター分析を行なった結果，諏訪湖底質は，流入河川 底質, 道路脇土壤と同一のクラスターに分類され, さら にこのクラスターには起源試料のディーゼル排出物や舗 装材中のPAHs を含吉画分 (S2) が分類されていた (Fig. 6 )。

\section{4. 考察}

\section{1 諏訪湖および流入河川における PAHs の分布}

流入河川底質では, 湖内底質に比べ乾重量当たりの 17PAHs 濃度が有意に低かった。これは, 諏訪湖と流入 河川底質の性状の違いが影響しているためと考えた。本 研究の結果より, 諏訪湖底質は流入河川底質に比べ, 底 質の圧密度が小さい、すなわち粒形が小さく ${ }^{10,111}$, 有機 物量が多い性状を持つことが明らかとなった。PAHsの ような疎水性の化学物質は, 一般に粒径が小さく, 有機 物量の多い性質の粒子に吸着しやすく ${ }^{6}$, これを裏付け るように, 本研究でも底質中の $\sum 17 \mathrm{PAHs}$ 濃度と灼熱減 量には正の相関が見られ， $\sum 17 \mathrm{PAHs}$ 濃度とみかけ密度 には負の相関が見られた。この底質の性状を左右するも
のとして河川水と湖水の流速の違いが挙げられる。すな わち, 河川や河口付近では, 流速が早く, PAHsを多く 吸着する微細な粒子が堆積できず，流速の緩やかな湖内 で堆積する。これが, 両者の乾重量あたりの濃度差を決 定している要因と言えよう。

一方, 諏訪湖底質中 $\sum 17 \mathrm{PAHs}$ 濃度の湖内に㧍ける分 布を調査した結果，北東部（L1，L2，L9）でやや濃度が 高い傾向が見られたが, 各地点の濃度差は最大でも約 5 倍程度であり（最小濃度地点 L15：197ng/g-dry, 最大濃 度地点 L2: $1598 \mu \mathrm{g} / \mathrm{g}$-dry), PAHs は湖内でほぼ均一に分 布していた。豊田ら ${ }^{14}$ は諏訪湖特有の西北西の風によ り, 湖全層で反時計回りの湖流が形成されることを明ら かにしている。湖内で濃度差が小さかったのは, 諏訪湖 のように浅く，風の影響を受けやすい湖では，形成され た湖流により微細な粒子が移動し, それに吸着した PAHs も湖内全面に拡散したものと考えられた。一方, やや PAHs 濃度が高かった諏訪湖北東部では，湖流の流 速が低下することが豊田ら ${ }^{14}$ の調査によって示されてい る。さらに, この地点には水草のヒシ (Trapa natans) が夏季に繁茂する。Nakajima et al. ${ }^{15}$ は陸上植物のサク ラやカエデ, イチョウに打いて, PAHs が葉のクチクラ 層に吸着されることを示している。ヒシは浮葉植物であ るため，陸上植物と同様に大気中の PAHs を吸着すると 考えられる。諏訪湖北東部の底質で見られた, やや高い PAHs 濃度は, 湖流の流速低下による微細な粒子の沈降 と, 水草による大気からの PAHs の吸着といった, 相乗 的な効果によるものと予想される。 

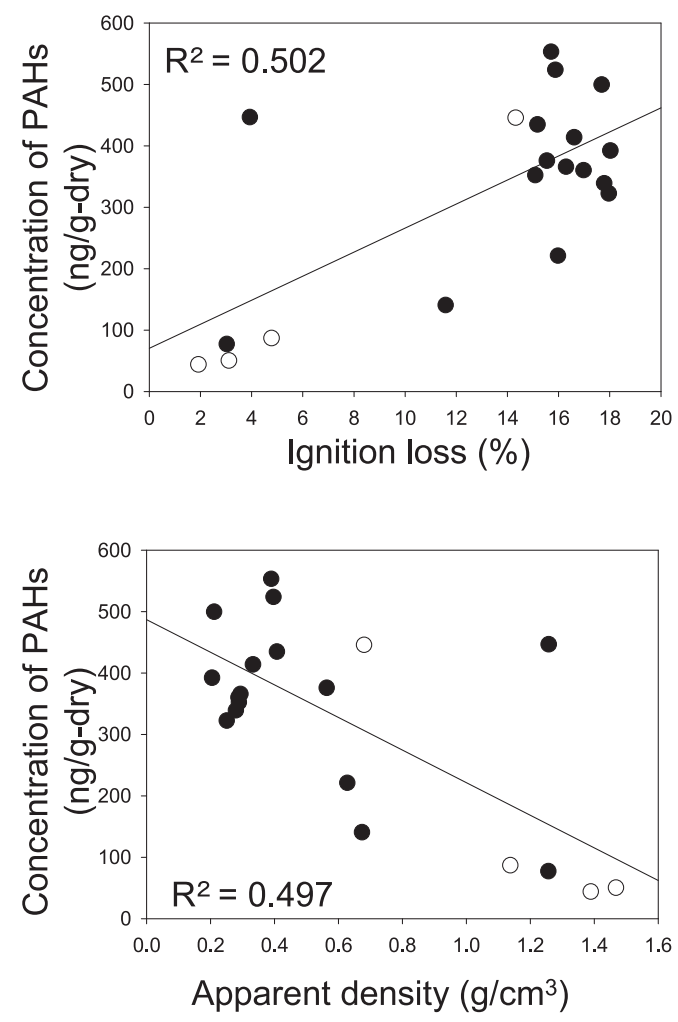

Fig. 4 Correlation between ignition loss, apparent density and concentration of $\Sigma 17 \mathrm{PAHs}$ Upper figure shows the correlation between ignition loss and concentration of $\Sigma 17 \mathrm{PAHs}$ $\left(\mathrm{R}^{2}=0.502\right)$. Lower figure shows the correlation between apparent density and concentration of $\Sigma 17 \mathrm{PAHs}\left(\mathrm{R}^{2}=0.497\right)$.

- shows the lake sediment, and $\bigcirc$ shows the river sediment

\section{2 Perylene について}

本研究の結果より, 諏訪湖底質で流入河川底質に比 べ, Per 濃度が非常に高いことが明らかになった。諏訪 湖底質中 PAHs は約 $60 \%$ が Perであったが，流入河川底 質では Perの占める割合は約 $8 \%$ 程度であり, 諏訪湖底 質に比べ, 少ない。一方, 湖沼底質中 ${ }^{16-21)}$ や海洋底質 中 ${ }^{22-24)}$ で Per 濃度が高いことが数多く報告されている。 例えば, Barra et al. ${ }^{16}$ はチリの山岳湖沼で Per 濃度が全 PAHs の60～90\%以上を占めていることを明らかにして いる。また, Jiang et $\mathrm{al} .{ }^{17)}$ は, 湖沼底質の高い Per 濃度は Perの安定性や有機物の然焼による発生だけでは説明で きず, 高等植物や菌類, 昆虫に含まれる色素である perylenequinone から還元状態でPerが生成されるとして いる。諏訪湖の下層は夏季に貧酸素状態になることが知 られており, 底質表層においても, 溶存酸素濃度が

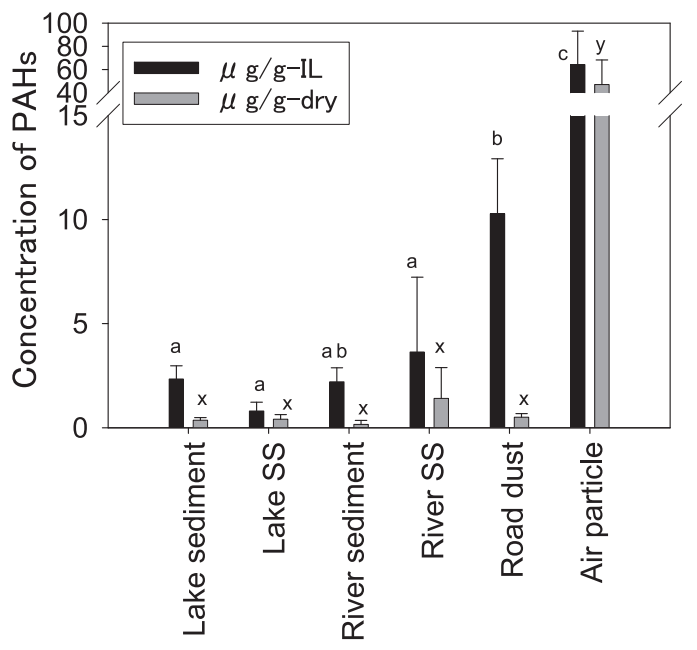

Fig. 5 Concentration of $\sum 17 \mathrm{PAHs}$ in lake sediment, lake SS, river sediment, river SS, road dust and air particle

Solid bar shows the average concentration of each sample and $\mathrm{T}$ line shows the standard deviation (lake sediments $n=16$, lake SS $n=$ 19 , river sediments $\mathrm{n}=4$, river $\mathrm{SS} \mathrm{n}=82$, road dusts $n=4$, air particles $n=3$ )

Alphabet shows the significant difference due to Tukey-kramer test

$0.3 \mathrm{mg}-\mathrm{O}_{2} / \ell$ 以下といった還元的な環境が生じる。諏訪 湖底質中の Per も物質の燃焼だけでなく，このような貧 酸素による還元的な環境で生成されている可能性が高 い。

\section{3 Perylene 以外の PAHs について}

クラスター分析を行なった結果, 諏訪湖底質, 流入河 川底質, 道路脇土壤は全てディーゼル排出物, 道路舗装 材を含む画分に分類された。また，濃度では，諏訪湖底 質中 $\sum 17 \mathrm{PAHs}$ 濃度 $(2.3 \pm 0.6 \mu \mathrm{g} / \mathrm{g}-\mathrm{IL})$ に対し, 大気浮 遊粉じん中（64.2 $28.7 \mu \mathrm{g} / \mathrm{g}$-IL）および道路脇土壤中 $(10.3 \pm 2.6 \mu \mathrm{g} / \mathrm{g}-\mathrm{IL})$ で有意に高く，さらに，流入河川 SS 中 $\sum 17 \mathrm{PAHs}$ 濃度も, 諏訪湖底質中 $\sum 17 \mathrm{PAHs}$ 濃度よ り高い傾向が見られた。すなわち, 諏訪湖底質中の PAHs の起源はディーゼル排出物や道路舗装材などが主 であり, それらが大気浮遊粉じんや道路脇土壤を経て, 流入河川を通じ諏訪湖底質に堆積しているため，このよ うな濃度の違いが生じたものと考えられた。ディーゼル 排出物や道路舗装材が粉じん中 PAHs の主要な起源とす る報告は日本の各地でなされている ${ }^{13,25)}$ 。小瀬ら ${ }^{25)}$ は岡 山市内主要幹線道路の道路脇土壤を採取し，トリテルパ ン類を指標にPAHs の起源推定を行なった結果, 夕イヤ 磨耗物および道路舗装材（アスファルト）磨耗物である 
Table 3 Categorized PAHs profiles reported by Pengchai et al. ${ }^{13)}$

\begin{tabular}{lcccccc}
\hline & \multicolumn{7}{c}{ Source groups } \\
\cline { 2 - 7 } & $\mathrm{S} 1$ & $\mathrm{~S} 2$ & $\mathrm{~S} 3$ & $\mathrm{~S} 4$ & $\mathrm{~S} 5$ & S6 \\
\hline Diesel exhausts & 0 & 3 & 10 & 3 & 7 & 0 \\
Gasoline exhausts & 0 & 0 & 1 & 8 & 24 & 12 \\
Tire & 8 & 0 & 0 & 0 & 0 & 0 \\
Road materials & 0 & 6 & 2 & 0 & 0 & 0 \\
\hline Naphthalene & 1.0 & 3.8 & 6.5 & 42.7 & 81.0 & 59.7 \\
Acenaphthylene & 1.5 & 1.0 & 0.3 & 4.8 & 4.0 & 0.8 \\
Acenaphthene & 0.0 & 0.3 & 0.0 & 0.8 & 3.8 & 13.1 \\
Fluorene & 0.4 & 3.1 & 0.5 & 4.6 & 2.5 & 0.9 \\
Phenanthrene & 5.0 & 15.6 & 33.7 & 19.9 & 2.2 & 2.1 \\
Anthracene & 0.4 & 1.8 & 1.3 & 3.0 & 1.7 & 4.0 \\
Fluoranthene & 11.9 & 7.5 & 17.1 & 9.2 & 1.0 & 3.0 \\
Pyrene & 43.5 & 13.7 & 27.7 & 10.0 & 1.4 & 2.9 \\
Benz[a]anthracene & 0.5 & 3.8 & 1.9 & 0.7 & 0.5 & 6.3 \\
Chrysene & 3.5 & 11.6 & 3.8 & 1.1 & 0.2 & 1.2 \\
Benzo b k fluoranthenes & 3.6 & 14.2 & 2.9 & 1.3 & 0.6 & 2.7 \\
Benzo[a]pyrene & 3.9 & 6.7 & 1.1 & 0.5 & 0.2 & 0.8 \\
Indeno[1,2,3-cd]pyrene & 5.7 & 3.9 & 0.7 & 0.5 & 0.2 & 0.5 \\
dibenz[a,h]anthracene & 0.3 & 2.7 & 0.1 & 0.4 & 0.4 & 1.7 \\
Benzo[ghi]perylene & 18.9 & 10.4 & 2.3 & 0.5 & 0.3 & 0.4 \\
\hline
\end{tabular}

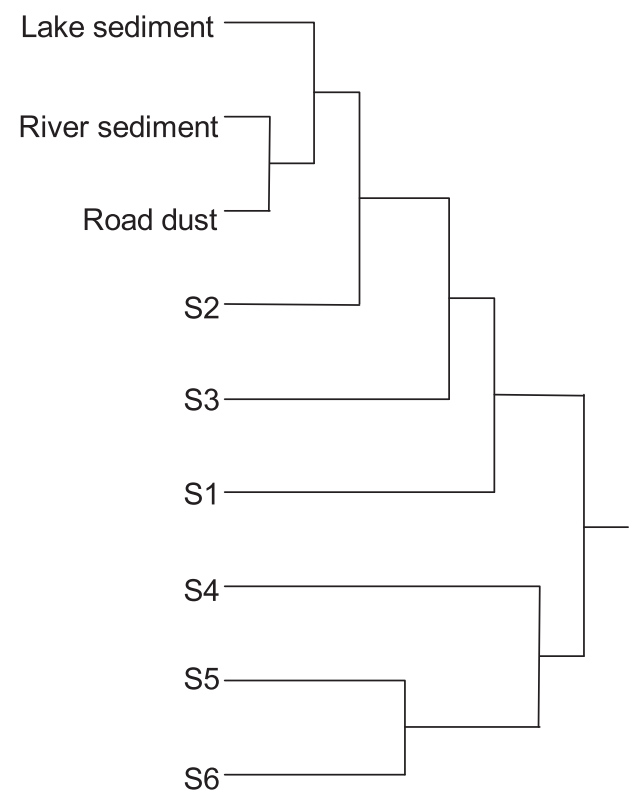

Fig. 6 Cluster analysis of each sample based on the Euclidean distance method

$\mathrm{S} 1 \sim \mathrm{S} 6$ shows the categorized PAHs profiles reported by Pengchai et al. ${ }^{13)}$

ことを報告している。また, ペンシャイら ${ }^{13)}$ は, 東京都 内の環七通りと桜田通りの道路側溝堆積物中の PAHs を 調査し, 環七通りでは夕イヤ磨耗物, 桜田通りでは ディーゼル排出物が PAHs 含量に大きく寄与しているこ
とを示している。 Smirnov et $\mathrm{al}^{\left.2{ }^{26}\right)}$ は, 五大湖の一つエ リー湖の PAHs の流入源を詳細に調査し，大気との分配 による湖内への PAHsの取り込みよりも，デトロイトな どの主要都市を流れる河川からの PAHs 流入による寄与 が大きいことを報告している。さらに，諏訪湖において も, 宮原 ${ }^{27)}$ は流入河川 (上川, 宮川, 砥川, 横河川）から 湖内に直接流入する PAHs 量と, 流出河川（天竜川）か ら直接流出する PAHs 量がそれぞれ約 $15 \mathrm{~kg} / \mathrm{yr}$, 約 5 $\mathrm{kg} / \mathrm{yr}$, すなわち, 年間 PAHs 堆積量を約 $10 \mathrm{~kg} / \mathrm{yr}$ と示して いる。一方, 本研究によって得られた諏訪湖底質中の PAHs 濃度と, 諏訪湖堆積物の年間平均堆積速度 5 )から, PAHs の年間堆積量を推定すると, 約 $6 \mathrm{~kg} / \mathrm{yr}$ であり, 堆

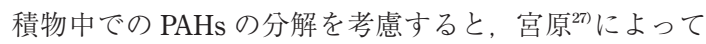
得られた結果を支持するとともに, PAHs の河川からの 流入負荷が強い事が分かる。これらの結果は, 諏訪湖の ように, 集水域面積が広く, 集水域における人間活動の 活発な湖沼では, 粒子に強く結合したPAHs が河川を介 し流入し，その底質に移行していると言える。

また，道路舗装材中の主要な PAHs である $\mathrm{BbF}, \mathrm{BkF}$ の毒性は $\mathrm{BaP} 1$ とした毒性等価係数でそれぞれ 1.6，9.6であり，PAHsの中でも毒性が強い7。これら PAHs の湖沼生態系への影響は未だ明らかとされていな いが, PAHs の流入負荷量を減少させるためにも, 今後, 道路舗装材の湖沼への流入を防ぐ必要があると言えよ う。 


\section{5. まとめ}

本研究の調査結果より, 諏訪湖底質中 PAHs の起源 は，ディーゼル排出物や道路舗装材が主であると考えら れた。これは，環境媒体である大気浮遊粉じんや道路脇 土壤中の高い PAHs 濃度やその PAHs 組成から示された。 これら発生源から放出されたPAHs は, 粒子とともに降 雨等により河川に流入し, 最終的には湖内底質に移行す る。一方, 諏訪湖底質中や諏訪湖 SS 中の PAHs 濃度は流 入河川 SS 中 PAHs 濃度よりも低かった。これは, 諏訪湖 湖内で増殖した植物プランクトン等の有機物による希釈 効果によるものと考えられた。

\section{謝 辞}

本報をまとめるにあたり，多大なご助言をいただいた 信州大学理学部物質循環学科および信州大学山岳科学総 合研究所の関係各位には深く感謝いたします。特に，信 州大学山岳科学総合研究所花里孝幸先生, 佐久間昌孝氏 には総括的なご指導，ならびに試料採取にご協力いただ き厚く御礼申し上げます。また, 諏訪湖の湖流デー夕を 快く提供していただいた信州大学工学部豊田政史先生に はこの場をお借りして感謝申し上げます。

\section{要 約}

湖沼環境はその集水域の環境を反映しており，特に富 栄養湖は人間活動に伴う化学物質の流入による影響を強 く受けている。我々は富栄養湖である諏訪湖において, 有害化学物質である多環芳香族炭化水素類 (PAHs) に よる污染の実態を調査し, その発生源, 流入経路の解明 を試みた。その結果, 諏訪湖底質中の主要な PAHs は peryleneであり，底質中で前駆物質 (perylenequinone 等）の還元により生じることが示唆された。一方, perylene 以外の PAHs は，主にディーゼル排出物や道路 舗装材が主な発生源であることが示され，それらが流入 河川を介し諏訪湖底質に移行していることが示された。

\section{文 献}

1）小椋和子：諏訪湖ワカサギの DDT および PCB と淩 渫, 水, 259, 41-44（1999）

2）佐々木一敏, 小澤秀明, 川村 實, 掛川英男, 清水 重德：諏訪湖底質中における有機塩素化合物の動 態，用水と排水，39，136-140（1997）

3）寺島 滋, 井内美朗, 中尾征三, 米谷 宏：諏訪湖 底質中の重金属, 有機炭素, 硫黄, りん等14元素の 地球化学的研究, 地質調査所月報, 41, 147-172 (1990)
4）寺島 滋, 井内美朗, 宮田雄一郎, 片山 肇, 斉藤 文紀，安田 聰，渡辺和明，吉川秀樹，稲崎富士： 諏訪湖底質中の重金属等11元素の地球化学的研究, 地質調査所月報, 43，549-564（1992）

5) Ikenaka, Y., Eun, H., Watanabe, E., Kumon, F. and Miyabara, Y.: Estimation of sources and inflow of dioxins and polycyclic aromatic hydrocarbons from the sediment core of lake Suwa, Japan. Environ. Pollut., 138, 530-538 (2005 a)

6) Ikenaka, Y., Eun, H., Watanabe, E. and Miyabara, Y.: Sources, distribution, and inflow pattern of dioxins in the bottom sediment of lake Suwa, Japan. Bull. Environ. Contam. Toxicol., 75, 915-921 (2005 b)

7) Till, M., Riebniger, D., Schmitz, H.J. and Schrenk, D.: Potency of various polycyclic aromatic hydrocarbons as inducer of CYP1A1 in rat hepatocyte cultures. Chem. Biol. Interact., 117, 135-150 (1999)

8) Xue, W. and Warshawsky, D.: Metabolic activation of polycyclic and heterocyclic aromatic hydrocarbons and DNA damage: A review. Toxicol. Appl. Pharm., 206, 73-93 (2005)

9) Baird, W.M., Hooven, L.A. and Mahadevan, B.: Carcinogenic polycyclic aromatic hydrocarbon-DNA adducts and mechanism of action. Environ. Mol. Mut., 45, 106-114 (2005)

10）公文富士夫, 田原敬治, 山本雅道：信州, 木崎湖に おける最近の堆積物の年代と堆積速度, 信州大学山 地水環境教育研究センター研究報告, 3, 77-84 (2004)

11) Adhikari, D.P. and Kumon, F.: Climatic changes during the past 1300 years as deduced from the sediments of Lake Nakatsuna, central Japan. Limnology, 2, 157-168 (2002)

12）赤岡 輝：水質の変遷，pp28-43,「アオコが消えた 諏訪湖 - 人と生き物のドラマ」, 沖野外輝夫他編集, 信濃毎日新聞社発行，長野市南県町657（2005）

13）ペッペンシャイ, 中島典之, 古米弘明：自動車排出 物, タイヤおよび道路舗装材の PAHs プロファイル とそれらの側溝堆積物中 PAHs への寄与, 環境科学 会誌, 15, 433-442（2002）

14）豊田政史, 宮原一道, 萩庭康光, 寺沢和晃, 正 田 真, 降矢利勝, 宮原裕一, 富所五郎：諏訪湖に おける湖上風の非一様性とそれが湖流形成に与える 影響, 水工学論文集, 50，1303-1308（2006）

15) Nakajima, D., Kojima, E., Iwaya, S., Suzuki, J. and Suzuki, S.: Presence of 1-hydroxypyrene conjugates in woody plant leaves and seasonal changes 
in their concentrations. Environ. Sci. Technol., 30, 1675-1679 (1996)

16) Barra, R., Popp, P., Quiroz, R., Treutler, H.C., Araneda, A., Bauer, C. and Urrutia, R.: Polycyclic aromatic hydrocarbons fluxes during the past 50 years observed in dated sediment cores from Andean mountain lakes in central south Chile. Ecotox. Environ. Safe., 63, 52-60 (2006)

17) Jiang, C., Alexander, R., Kagi, R.I. and Murray, A.P.: Origin of perylene in ancient sediments and its geological significance. Org. Geochem., 31, 15451559 (2000)

18) Jones, B.G.K.C. and Hamilton-Taylor, J.: Polycyclic aromatic hydrocarbons (PAH) deposition to and processing in a small rural lake, Cumbria UK. Sci. Total Environ., 215, 231-242 (1998)

19) Silliman, J.E., Meyers, P.A. and Eadie, B.J.: Perylene: an indicator of alteration processes or precursor materials. Org. Geochem., 29, 1737-1744 (1998)

20) Silliman, J.E., Meyers, P.A., Ostrom, P.H., Ostrom, N.E. and Eadie, B.J.: Insights into the origin of perylene from isotopic analyses of sediments from Saanich Inlet, British Columbia. Org. Geochem., 31, 1133-1142 (2000)

21) Wakeham, S.G., Schaffner, C. and Giger, W.: Polycyclic aromatic hydrocarbons in recent lake sediments-II. Compounds derived from biogenic precursors during early diagenesis. Geochemi. Cosmochim. Ac., 44, 415-429 (1980)

22) Boonyatumanond, R., Wattayakorn, G., Togo, A. and Takada, H.: Distribution and origins of polycyclic aromatic hydrocarbons (PAHs) in riverine, estuarine, and marine sediments in Thailand. Mar. Pollut. Bull., 52, 942-956 (2006)

23) Dahle, S., Savinov, V.M., Matishov, G.G., Evenset, A. and Nas, K.: Polycyclic aromatic hydrocarbons (PAHs)in bottom sediments of the Kara Sea shelf, Gulf of $\mathrm{Ob}$ and Yenisei bay. Sci. Total Environ., 306, 57-71 (2003)

24) Yang, G. P.: Polycyclic aromatic hydrocarbons in the sediments of the South China Sea. Environ. Pollut., 108, 163-171 (2000)

25）小瀬知洋, 山本高士, 姉川 彩, 毛利紫乃, 小野芳 郎：道路塵埃および排水中の多環芳香族炭化水素類 の污染源の検討, 環境科学会誌, 19, 461-469 (2006)

26) Smirnov, A., Abrajano, T.A. Jr., Smirnov, A. and Stark, A.: Distribution and sources of polycyclic aromatic hydrocarbons in the sediments of Lake Erie, Part 1. Spatial distribution, transport, and deposition. Org. Geochem., 29, 1813-1828 (1998)

27）宮原裕一：諏訪湖における多環芳香族炭化水素類の 収支に関する研究, 河川整備基金助成事業報告書, 課題番号16-1- 1)-13（2004） 